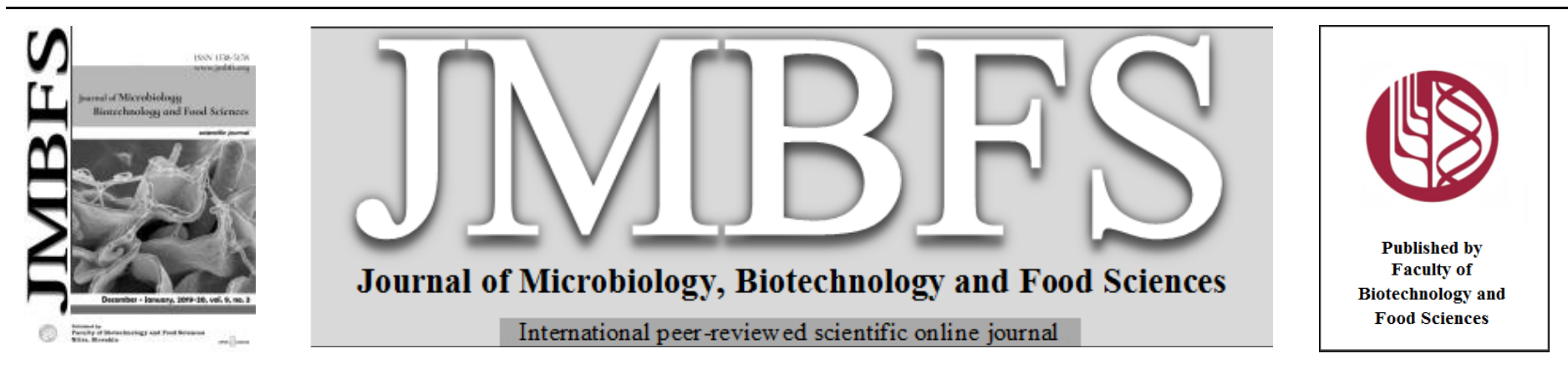

\title{
EFFECTS OF POPPY OIL ON BIOGENIC AMINE IN FERMENTED TURKISH SAUSAGE
}

\author{
Beyza AYDOGAN ${ }^{1}$, A. Fatih FIDAN ${ }^{1}$, Recep KARA2*
}

Address(es):

${ }^{1}$ Afyon Kocatepe University, Faculty of Veterinary Medicine, Department of Biochemistry, 03200, Afyonkarahisar, Turkey.

${ }^{2}$ Afyon Kocatepe University, Faculty of Veterinary Medicine, Department of Food Hygiene and Technology, 03200, Afyonkarahisar, Turkey.

*Corresponding author: recepkara@aku.edu.tr

doi: $10.15414 /$ jmbfs.2019/20.9.3.530-533

\section{ARTICLE INFO}

Received 30.1.2019

Revised 13. 5. 2019

Accepted 30. 5. 2019

Published 1. 12. 2019

Regular article OPEN $\partial_{\text {ACCESS }}$

\begin{abstract}
Biogenic amines are generally created by the decarboxylation of amino acids via microbial enzymes and these compounds may have a toxic effect on humans and animals. The ripening and storage conditions of meat and meat products directly affect the quality of such products in terms of biogenic amines. The aim of this study was to investigate the effects of poppy oil, which is produced and consumed in large quantities in Afyonkarahisar province, on the formation of biogenic amines in fermented sausages. In the study, 2 groups of sausages were produced including control and poppy oil groups. $300 \mathrm{mg} / \mathrm{kg}$ poppy oil was added to the sausage that would be produced in the poppy oil group. The sausages were ripened for 15 days in the surrounding where relative humidity (90-60\%) and the temperature $\left(25-18^{\circ} \mathrm{C}\right)$ could be adjusted. During this period $(0,2,4,6,8,10,13$ and 15 days), physico-chemical, sensory, microbiological properties and biogenic amine (histamine, putresin, tryptamine, phenyl ethylamine and tyramine) formations were determined in the samples. As a result, it is recommended that the poppy oil used does not cause a significant difference in the formation of biogenic amines, does not adversely affect the general characteristics of the sausage and that the amount of animal fat is reduced and alternatively, the use of poppy oil in the production of fermented sausage is recommended.
\end{abstract}

Keywords: Poppy oil, Biogenic amine, Fermented sausage

\section{INTRODUCTION}

Sausage is one of the most popular traditional fermented meat products produced in Turkey (Genis and Tuncer, 2018). Ripening process of sausage depends on many complex reactions as well as the interaction of these reactions. Chemical, biochemical and microbiological changes occur during production; furthermore these changes create the characteristic flavor of the product (Coskuner et al., 2010).

Biological amines formed as a result of microbial activity in food products have lower molecular weight. Almost all fermented foods contain free amino acids or proteins. Biogenic amine formation is an expected result when microbial or biochemical activity conditions are met properly (Ten Bring et al., 1990). Biogenic amines in foods are important for two reasons. First, the amount of biogenic amine is considered to be a quality indicator whereas the other factor is bound to be the presence of toxic effects on health. Since decarboxylase activity is increased during microbial spoilage of foods, the presence of biogenic amines is of importance because it is the indicator of food spoilage (Bardocz, 1995).

Major biogenic amines formed in nutrients are putresine, cadaverine, histamine, tyramine, tryptamine, 2-phenylethylamine, spermine, spermidine, methylamine, agmatine, ethylamine and ethanolamine (Shalaby, 1996; Toy, 2010). Biogenic amines have important biological functions in the body. They form the first step in the synthesis of protein, hormone and nucleic acid. They can also affect the body temperature balance and increase or decrease the blood pressure. Polyamines are essential for the development of all organs in the body, for the regeneration and metabolism of the cells, and for the strengthening of the immune system. However, consumption of foods containing high concentrations of these compounds may cause toxic reactions. It is very difficult to give precise limits on the toxicity of biogenic amines. Because, the type of food consumed, the amount and the presence of inhibitors with the content of the amine make it difficult to determine the limits related to the toxicity of biogenic amines (Santos, 1996). Typical symptoms of biogenic amine poisoning are listed as diarrhea, nausea, headache, hyper- or hypotension (Yerlikaya and Gokoglu, 2002)

Poppy is a single-year cultivated plant as Papaver somniferum $L$ type of the Papaveraceae family in the Rhoedales family (Anonymous, 2017). Poppy oil has colors ranging from light yellow to dark yellow. Poppy oil is also semi-drying; it has a pleasant smell and taste (Koc et al., 2006). Poppy oil consists of an average of $11.0 \%$ palmitic, $0.4 \%$ palmitoleic, $1.9 \%$ stearic, $15.0 \%$ oleic, $71.3 \%$ linoleic and $0.6 \%$ linolenic fatty acids (Atakisi, 1991). Poppy oil is rich in Omega-6 and Omega-9 fatty acids. This oil contains high levels of vitamin E. It has antioxidant effect. It forms important building blocks of tissue cells in our body. It strengthens the immune system. Regulates blood circulation. Helps skin look younger, looks younger and regulates the functions of all skin cells (Anonymous, 2012). On the other hand, calorie taken with animal fat is the same as calories from other fatty acids; causes fat accumulation and weight gain in the body (Altunkaynak et al., 2006). It prevents the removal of low density lipoprotein (LDL, bad cholesterol) in the blood. As a result, it can cause atherosclerosis by forming deposits in the vessels (Baysal, 2002). Therefore, in order to avoid health problems, poppy oil may be preferred instead of animal fat.

In similar studies, the effects of various oils have been documented on of biogenic amine formation in different foods such as zahter oil (a blend of powdered thyme) (Bozkurt, 2006), yoghurt (Somer, 2013), olive (Ozdestan et al., 2011), fish and fish products (Olgunoglu et al., 2009). In this study, the effect of poppy oil on the formation of biogenic amines in fermented sausage was investigated accordingly.

\section{MATERIAL AND METHODS}

\section{Sausage Preparation}

Sausage paste was prepared by mixing $80 \%$ red meat and $20 \%$ oil with $2 \%$ salt, $0.6 \%$ sucrose sugar, $1 \%$ dried garlic, $0.7 \%$ red pepper, $0.5 \%$ powdered black pepper, $0.9 \%$ cumin, \% $0,25 \mathrm{~kg}$ allspice (Gokalp et al., 1999).

The prepared sausage paste was divided into two parts: as control and poppy group. Some (additive-free) part formed one group. The other group was prepared as two different types of sausage samples by adding $300 \mathrm{mg} / \mathrm{kg}$ of poppy oil. The prepared sausages were ripened for 15 days in the relative humidity $(90-60 \%)$ and the temperature $\left(25-18^{\circ} \mathrm{C}\right)$.

\section{Sampling}

During the ripening phase, samples were taken from the sausage samples on the days $0,2,4,6,8,10,13$ and 15 , then their physico-chemical, sensory and 
microbiological properties and formation of biogenic amine (histamine, putresin, tryptamine, phenyl ethylamine and tyramine) were determined.

\section{Microbiological Analyses}

For microbiological evaluation of the samples, $90 \mathrm{ml}$ of peptoned water was added to the $10 \mathrm{~g}$ sample and the mixture homogenized. It was then diluted to 107-8 with serial dilutions. From the prepared dilutions, planting was made for total mesophilic aerobic bacteria count (TMAB) (ISO 4833, 2003), lactic acid bacteria count (LAB) (Lopez-Diaz et al., 2000) and yeast-mold count (Pichhardt, 1993).

\section{Physico-Chemical Analyses}

The humidity determination of the sausage samples was carried out according to ISO 1442 (1997), while $\mathrm{pH}$ values were measured using WTW brand (Microprocessor pH meter, Germany) pH meter ISO 2917 (1999), and titratable acidity was determined according to Gokalp (1993).

\section{Color Measurement}

Color analysis of sausage samples was realized with (B * (Brightness), $\mathrm{r} *$ (redness and $\mathrm{y} *$ (yellowness) using Minolta (CR-A70, Japan) color measurement device.

\section{Sensory Evaluation}

Sensory evaluation of the samples was performed by panelists $(n=10)$. The panelists were trained on the quality characteristics of sausages before going into consideration. The sensory evaluation of the samples was carried out at the same

time in all repeats under the fluorescent light. The panelists evaluated the color and appearance, taste and aroma, texture, and taste of sausages in terms of general taste. The panelists were given water and bread to avoid interactions between the samples. They made the evaluations using hedonic scale via points 1 - 3 (very bad - unacceptable), 4-5 (moderate), 6-7 (good), 8-9 (very good) (Altug, 1993)

\section{Biogenic Amine Analysis}

The levels of biogenic amines (histamine, putresine, tryptamine, phenyl ethylamine and tyramine) in the sausage samples were determined using the HPLC tool. Biogenic amine analysis in sausage samples were carried out at Mehmet Akif Ersoy University, Scientific and Technological Application and Research Center. Prepared samples were centrifuged according to the HPLC method via Shimadzu Prominence Brand adding $10 \mathrm{~mL}$ of $0.6 \mathrm{~N}$ perchloric acid to $10 \mathrm{~g}$ of sample and at $4000 \mathrm{rpm}$ for 4 minutes at $20^{\circ} \mathrm{C}$. The supernatant liquid was incubated with $100 \mu \mathrm{l} 2 \mathrm{~N} \mathrm{NaOH}, 150 \mu \mathrm{l}$ of saturated sodium bicarbonate and $1 \mathrm{~mL}$ of densyl chloride and then incubated at $40{ }^{\circ} \mathrm{C}$ for 45 minutes. After keeping at room temperature for 10 minutes, $50 \mu \mathrm{l}$ of $25 \% \mathrm{NH} 3$ was added and the mixture was again kept at room temperature for a further 30 minutes. $5 \mathrm{~mL}$ of ammonium acetate was added to it and filtered through a $0.45 \mu \mathrm{m}$ filter, and then injected into the HPLC system.

\section{RESULTS AND DISCUSSION}

In the study putresin, histamine, tyramine, tryptamine, PEA (phenyl ethyl amine) levels determined in the sausage samples during fermentation are shown in Table 1 .

Table 1 Levels of Putrescine, Histamine, Tiramine, Triptamine, PEA (phenyl ethyl amine) in the sausage samples during fermentation period

\begin{tabular}{lccccccccccc}
\hline $\begin{array}{l}\text { Time } \\
(\text { day })\end{array}$ & \multicolumn{2}{c}{$\begin{array}{c}\text { Putrescine } \\
(\%-\mu \mathrm{g} / \mathrm{g})\end{array}$} & \multicolumn{2}{c}{$\begin{array}{c}\text { Histamine } \\
(\%-\mu \mathrm{g} / \mathrm{g})\end{array}$} & \multicolumn{2}{c}{$\begin{array}{c}\text { Tyramine } \\
(\%-\mu \mathrm{g} / \mathrm{g})\end{array}$} & \multicolumn{2}{c}{$\begin{array}{c}\text { Tryptamine } \\
(\%-\mu \mathrm{g} / \mathrm{g})\end{array}$} & \multicolumn{2}{c}{$\begin{array}{c}\text { PEA } \\
(\%-\mu \mathrm{g} / \mathrm{g})\end{array}$} \\
\cline { 2 - 12 } & $\mathrm{K}$ & $\mathrm{H}$ & $\mathrm{K}$ & $\mathrm{H}$ & $\mathrm{K}$ & $\mathrm{H}$ & $\mathrm{K}$ & $\mathrm{H}$ & $\mathrm{K}$ & $\mathrm{H}$ \\
\hline $\mathbf{0}$ & 0.29 & 0.23 & 0.16 & 0.12 & 0.11 & 0.09 & 0.03 & 0.03 & 39.59 & 42.61 \\
\hline $\mathbf{2}$ & 0.63 & 0.67 & 0.23 & 0.13 & 0.21 & 0.11 & 0.05 & 0.11 & 62.69 & 48.47 \\
\hline $\mathbf{4}$ & 0.76 & 0.68 & 0.11 & 0.11 & 0.21 & 0.14 & 0.21 & 0.25 & 59.73 & 51.50 \\
\hline $\mathbf{6}$ & 0.83 & 0.85 & 0.11 & 0.16 & 0.18 & 0.18 & 0.27 & 0.25 & 63.01 & 58.12 \\
\hline $\mathbf{8}$ & 0.83 & 0.80 & 0.10 & 0.15 & 0.20 & 0.16 & 0.37 & 0.32 & 61.51 & 54.18 \\
\hline $\mathbf{1 0}$ & 0.80 & 1.19 & 0.40 & 0.22 & 0.17 & 0.20 & 0.34 & 0.40 & 65.14 & 57.07 \\
\hline $\mathbf{1 3}$ & 0.84 & 0.67 & 0.22 & 0.28 & 0.23 & 0.18 & 0.43 & 0.37 & 67.72 & 55.62 \\
\hline $\mathbf{1 5}$ & 0.58 & 0.64 & 0.36 & 0.25 & 0.16 & 0.21 & 0.42 & 0.45 & 64.31 & 63.63 \\
\hline K: Control, H: Poppy & & & & & & & & & & &
\end{tabular}

Putrescine levels were revealed to have increased during the fermentation in both groups, while no significant difference was observed between the groups in terms of putrescine levels. Similar studies were conducted by Erkmen and Bozkurt (2004); Ten Brink et al. (1990). They found the amount of putrescine as 0.0 $918.9 \mathrm{mg} / \mathrm{kg}$ and $1-190 \mathrm{mg} / \mathrm{kg}$. Regarding the effect of the use of starter on the amount of putresine, many researchers reported that the addition of starter reduced the putresin formation, but did not prevent the formation (Roig-Sogues and Eerola, 1997; Hernandez-Jover et al., 1997; Ayhan et al., 1999; BoverCid et al., 2000).

At the end of the analysis in the histamine levels; the poppy group was detected to be at a lower level than the control group. In their study, Ten Brink et al. (1990), determined the amount of histamine in fermented sausages as between 1$63 \mathrm{mg} / \mathrm{kg}$. On the other hand, Buncic et al. (1993), revealed 0.3\% GDL, starter culture (Lactobacillus plantarum) and control group of sausage histamine concentration as 19, 41, 17, 20 and $18.64 \mathrm{mg} / \mathrm{kg}$ respectively. In their studies on the samples of histamine Ekici et al. (2004); Erkmen and Bozkurt (2004); Bozkurt and Erkmen (2004), reported the histamine levels to be 19.64-87.47, $1.5-478.2$ and $0.0-242.2 \mathrm{mg} / \mathrm{kg}$

For tyramine levels; no significant changes were observed in the control group the tyramine level was found to have increased during the fermentation in the poppy group. Similar studies were performed by Senoz et al. (2000); Erkmen and Bozkurt (2004), and they found that the amount of tyramine in sausage samples ranged between $125-1173.28$ and $1.2-316.3 \mathrm{mg} / \mathrm{kg}$, respectively. In the study of Ten Brink et al. (1990), the amount of tyramine was found to be 40-310 $\mathrm{mg} / \mathrm{kg}$ in fermented sausages. Coisson et al. (2004), detected that the most important biogenic amine in fermented dry sausage was tyramine $(372 \mathrm{mg} / \mathrm{kg}$ ). According to the results of the current study, tyramine was found to be the most important biogenic amine formed in the sausage, but other researchers found the amount to be lower (Ayhan et al., 1999; Senoz et al., 2000; Bozkurt and Erkmen, 2002; Colak and Ugur, 2002; Erkmen and Bozkurt, 2004).
Triptamine levels of sausage samples in both groups were determined to have increased during the fermentation; no significant difference was observed between the two groups in terms of tryptamine levels. Eitenmiller et al. (1978) revealed that tryptamine in starter cultured samples was formed in lower amounts than the control group. Bover-Cid et al. (2000, 2001a), regarding with amine negative Lactobacillus sakei and Staphylococcus spp. detected that tyramine cadaverine and putresine formation in fermented soes decreased and other amines did not form histamine, phenyl ethylamine and tryptamine. Bozkurt and Erkmen (2004), pointed out that tryptamine was not available in the samples at the beginning of ripening, and that the highest amount was found in the control group, whereas tryptamine formed in lower amounts in the starter cultured samples when compared to the control group.

PEA levels of the samples were detected to have increased during the fermentation in both groups. In terms of PEA levels, the poppy group was found to be lower when compared to the control group. Similar studies conducted by Ayhan et al. (1999), did not detect phenyl ethylamine in any of the sausage samples in their study. Bozkurt and Erkmen (2002), examined the effects of starter culture besides the use of different amounts of chemicals on biogenic amine formation and reported that phenyl ethylamine was not available in the samples. On their research of fermented sausages produced by adding sulfide, Bover-Cid et al. (2001b), determined that the tryptamine and phenyl ethylamine were not formed during the ripening period. Bover-Cid et al. (2001c), also found that phenyl ethylamine was created only in the sausages that were produced in

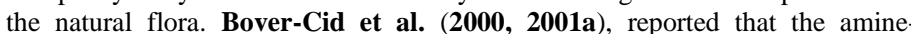
negative Lactobacillus sakei and Lactobacillus curvatus did not produce phenyl ethylamine. Ansorena et al. (2002), stated that Staphylococcus carnosus produced phenyl ethylamine. Ten Brink et al. (1990), determined the amount of phenyl ethylamine in fermented sausages ranging between 5-45 mg / kg. Bozkurt and Erkmen (2004), expressed that in many cases phenyl ethylamine was absent while in the determined samples, the amount was less than $30 \mathrm{mg} / \mathrm{kg}$.

In this study, total aerob mesophilic bacteria (TAMB), lactic acid bacteria and yeast / mold results determined in the sausage samples during fermentation are 
shown in Table 2. Bacterial numbers of TAMB and Lactic acid increased during the fermentation period. The yeast / mold levels of the poppy samples were found to be approximately $1 \log$ lower than the control group levels.

Table 2 Microbiological Analysis Findings

\begin{tabular}{|c|c|c|c|c|}
\hline Time (day) & Groups & TAMB & LAB & Yeast/Mold \\
\hline \multirow{2}{*}{0} & $\mathrm{~K}$ & 6.45 & 4.76 & 3.25 \\
\hline & $\mathrm{H}$ & 6.05 & 4.69 & 3.24 \\
\hline \multirow{2}{*}{2} & $\mathrm{~K}$ & 6.75 & 5.27 & 4.30 \\
\hline & $\mathrm{H}$ & 6.33 & 5.21 & 3.50 \\
\hline \multirow{2}{*}{4} & $\mathrm{~K}$ & 7.31 & 5.63 & 4.45 \\
\hline & $\mathrm{H}$ & 6.45 & 5.69 & 3.40 \\
\hline \multirow{2}{*}{6} & $\mathrm{~K}$ & 7.50 & 6.49 & 4.38 \\
\hline & $\mathrm{H}$ & 7.06 & 6.78 & 3.60 \\
\hline \multirow{2}{*}{8} & $\mathrm{~K}$ & 7.54 & 6.73 & 4.68 \\
\hline & $\mathrm{H}$ & 7.51 & 6.80 & 4.10 \\
\hline \multirow{2}{*}{10} & $\mathrm{~K}$ & 7.60 & 7.25 & 5.08 \\
\hline & $\mathrm{H}$ & 7.63 & 7.45 & 4.20 \\
\hline \multirow{2}{*}{13} & $\mathrm{~K}$ & 7.68 & 7.30 & 6.78 \\
\hline & $\mathrm{H}$ & 7.60 & 7.42 & 4.12 \\
\hline \multirow{2}{*}{15} & $\mathrm{~K}$ & 7.56 & 7.65 & 4.50 \\
\hline & $\mathrm{H}$ & 7.60 & 7.24 & 3.90 \\
\hline
\end{tabular}

TAMB: Total Aerobic Mesophilic Bacteria, LAB: Lactic Acid Bacteria, K Control, H: Poppy

The $\mathrm{pH}$, dry matter and acidity (\% LA) results of sausage samples during the fermentation period are shown in Table 3. In the course of the whole ripening, the $\mathrm{pH}$ generally did not fall below 5.0 and there was no significant difference between the two groups. In terms of dry matter and acidity values, an increase was detected during fermentation, however no significant difference was found between the two groups

Table 3 Chemical Analysis Findings

\begin{tabular}{lcccc}
\hline \multirow{2}{*}{ Time (day) } & Groups & Ph & Dyr Matter $(\boldsymbol{\%})$ & Acidity (\%LA) \\
\hline \multirow{2}{*}{0} & $\mathrm{~K}$ & 5.64 & 41.21 & 0.71 \\
& $\mathrm{H}$ & 5.65 & 41.21 & 0.71 \\
\hline \multirow{2}{*}{2} & $\mathrm{~K}$ & 5.31 & 44.20 & 0.82 \\
& $\mathrm{H}$ & 5.31 & 44.22 & 0.83 \\
\hline \multirow{2}{*}{4} & $\mathrm{~K}$ & 5.17 & 48.11 & 0.87 \\
& $\mathrm{H}$ & 5.11 & 48.16 & 0.87 \\
\multirow{2}{*}{6} & $\mathrm{~K}$ & 5.17 & 52.51 & 0.93 \\
& $\mathrm{H}$ & 5.17 & 53.15 & 0.96 \\
\multirow{2}{*}{8} & $\mathrm{~K}$ & 5.17 & 53.63 & 1.35 \\
& $\mathrm{H}$ & 5.11 & 54.15 & 2.10 \\
\multirow{2}{*}{10} & $\mathrm{~K}$ & 5.07 & 57.31 & 2.10 \\
\hline \multirow{2}{*}{13} & $\mathrm{H}$ & 4.97 & 58.20 & 2.15 \\
& $\mathrm{~K}$ & 5.00 & 58.23 & 2.15 \\
\multirow{2}{*}{15} & $\mathrm{H}$ & 4.90 & 58.35 & 2.19 \\
& $\mathrm{~K}$ & 5.00 & 60.49 & 2.18 \\
\hline \multirow{2}{*}{$\mathrm{C}$} & $\mathrm{H}$ & 4.95 & 61.91 & \\
\hline
\end{tabular}

K: Control, H: Poppy, LA: Lactic Acid

In the study, during the fermentation period, no significant change was observed in the r-redness and y-yellowness values in the color measurement findings in the sausage samples; on the other hand, b-brightness was found to be higher in the poppy group compared to the control group.

Table 4 Color Analysis Findings

\begin{tabular}{lccc}
\hline Groups & L & a & b \\
\hline $\mathrm{K}$ & 43.76 & 25.10 & 18.16 \\
\hline $\mathrm{H}$ & 44.19 & 25.15 & 18.55 \\
\hline
\end{tabular}

K: Control, H: Poppy, L: lightness, a: redness, b: yellowness

The sensory results of the study detected in the sausage samples during fermentation are shown in Table 5. In terms of the sensory values, the control group received higher evaluation scores compared to the poppy group in terms of appearance, bad smell and general taste, while there was no significant difference between the two groups in color and texture values.

Table 5 Sensory Analysis Findings

\begin{tabular}{lcccccc}
\hline Groups & Apperance & $\begin{array}{c}\text { Bad } \\
\text { Smell }\end{array}$ & Taste & Colour & Texture & General \\
\hline $\mathrm{K}$ & 8.17 & 8.33 & 7.50 & 7.83 & 7.50 & 8.17 \\
$\mathrm{H}$ & 7.50 & 8.17 & 7.17 & 7.83 & 7.50 & 7.50 \\
\hline
\end{tabular}

K: Control, H: Poppy

\section{CONCLUSION}

As a result, the poppy oil used in the ratio specified in the fermented sausage production did not adversely affect the general characteristics of the sausage. Poppy oil use was also revealed to have reduced histamine formation; microbiologically reduced the number of yeast molds by $1 \log$ via suppressing the proliferation. The amount of animal oil should be reduced, while the use of poppy oil is recommended alternatively in fermented sausage productions.

Acknowledgement: This study was supported by TUBITAK 1919B011600771 and presented as a summary in the International Conference on Agriculture, Forest, Food Sciences and Technologies (ICAFOF) Congress (Cappadocia, TURKEY).

\section{REFERENCES}

Altug, T. (1993). Sensory testing techniques. E. U. Faculty of Engineering Textbooks Publication, pp. 28 .56, Izmir (in Turkish).

Altunkaynak, B. Z., \& Özbek, E. (2006). Obesity: causes and treatment options Van Medical Journal,13(4), 138-142.

Ansorena, D., Montel, M. C., Rokka, M., Talon, R., Eerola, S., Rizzo, A., \& Demeyer, D. (2002). Analysis of biogenic amines in northern and southern European sausages and role of flora in amine production. Meat Science, 61(2), 141-147. https://doi.org/10.1016/S0309-1740(01)00174-7.

Anonymous. 2012. http://www.saglikbilgisi.gen.tr/ saglikli-yasamin-sirrikutsanmis-tohumlarda.html, (access date: 10.01.2012).

Anonymous. 2017. 2016 Poppy Sector Report. General Directorate of Turkish Grain Board. http://www.tmo.gov.tr/Upload/Document/hashassektrraporu.pdf (access date: 15.08.2017).

Atakisi, İ. K. (1991). Oil Crop Growing and Growing Textbook Notes. Trakya University, Tekirdag Agricultural Faculty, Publication No: 148, 118pp, Tekirdag (in Turkish)

Ayhan, K., Kolsarici, N., \& Özkan, G. A. (1999). The effects of a starter culture on the formation of biogenic amines in Turkish soudjoucks. Meat Science, 53(3), 183-188. https://doi.org/10.1016/S0309-1740(99)00046-7.

Bardócz, S. (1995). Polyamines in food and their consequences for food quality and human health. Trends in Food Science \& Technology, 6(10), 341-346. https://doi.org/10.1016/S0924-2244(00)89169-4.

Baysal, A. (2002). Nutrition. Hatipoglu Publications: 93, Sahin press, Ankara (in Turkish).

Bover-Cid, S., Izquierdo-Pulido, M., \& Vidal-Carou, M. C. (2000). Mixed starter cultures to control biogenic amine production in dry fermented sausages. Journal of Food Protection, 63(11), 1556-1562. https://doi.org/10.4315/0362-028X63.11.1556.

Bover-Cid, S., Hugas, M., Izquierdo-Pulido, M., \& Vidal-Carou, M. C. (2001a) Amino acid-decarboxylase activity of bacteria isolated from fermented pork sausages. International Journal of Food Microbiology,66(3), 185-189. https://doi.org/10.1016/S0168-1605(00)00526-2.

Bover-Cid, S., Miguélez-Arrizado, M. J., \& Vidal-Carou, M. C. (2001b) Biogenic amine accumulation in ripened sausages affected by the addition of sodium sulphite. Meat Science, 59(4), 391-396. https://doi.org/10.1016/S03091740(01)00091-2

Bover-Cid, S., Izquierdo-Pulido, M., \& Vidal-Carou, M. C. (2001c). Effect of the interaction between a low tyramine-producing Lactobacillus and proteolytic staphylococci on biogenic amine production during ripening and storage of dry sausages. International Journal of Food Microbiology, 65(1-2), 113-123. https://doi.org/10.1016/S0168-1605(00)00525-0.

Bozkurt, H., \& Erkmen, O. (2002). Effects of starter cultures and additives on the quality of Turkish style sausage (sucuk). Meat Science,61(2), 149-156 https://doi.org/10.1016/S0309-1740(01)00176-0.

Bozkurt, H., \& Erkmen, O. (2004). Effects of temperature, humidity and additives on the formation of biogenic amines in sucuk during ripening and storage periods. Food science and technology international, 10(1), 21-28. https://doi.org/10.1177/1082013204041992.

Bozkurt, H. (2006). The Effect of Zahter Oil on the Quality of Turkish Sausage. Turkey 9th Food Congress; 24-26 May 2006, Bolu, 923-926

Bunčić, S., Paunović, L. J., Teodorović, V., Radišić, D., Vojinović, G., Smiljanić, D., \& Baltić, M. (1993). Effects of gluconodeltalactone and Lactobacillus plantarum on the production of histamine and tyramine in fermented sausages. International Journal of Food Microbiology, 17(4), 303-309. https://doi.org/10.1016/0168-1605(93)90200-Z.

Coïsson, J. D., Cerutti, C., Travaglia, F., \& Arlorio, M. (2004). Production of biogenic amines in "Salamini italiani alla cacciatora PDO". Meat Science, 67(2), 343-349. https://doi.org/10.1016/j.meatsci.2003.11.007.

Coskuner, Ö., Ertaş, A. H., \& Soyer, A. (2010). The effect of processing method and storage time on constituents of Turkish sausages (sucuk). Journal of food processing and preservation, 34, 125-135.

Çolak, H., \& Uğur, M. (2002). The effect of different temperature and time in storage on the formation of biogenic amines in fermented sucuks. Turkish Journal of Veterinary and Animal Sciences, 26(4), 779-784. 
Eitenmiller, R. R., Koehler, P. E., \& Reagan, J. O. (1978). Tyramine in fermented sausages: factors affecting formation of tyramine and tyrosine decarboxylase. Journal of Food Science, 43(3), 689-693. https://doi.org/10.1111/j.1365-2621.1978.tb02394.x.

Ekici, K., Șekeroğlu, R., Sancak, Y. C., \& Noyan, T. (2004). A note on histamine levels in Turkish style fermented sausages. Meat science, 68(1), 123-125. https://doi.org/10.1016/j.meatsci.2004.02.013.

Erkmen, O., \& Bozkurt, H. (2004). Quality characteristics of retailed sucuk (Turkish dry-fermented sausage). Food Technology and Biotechnology, 42(1), 63-70.

Genis, B., \& Tuncer, Y. (2018). Determination of antibiotic susceptibility and decarboxylase activity of coagulase-negative Staphylococcus and Macrococcus caseolyticus strains isolated from fermented Turkish sausage (sucuk). Journal of Food Processing and Preservation, 42(1), e13329. https://doi.org/10.1111/jfpp.13329.

Gokalp, HY., Kaya, M., Tülek, Y., \& Zorba, Ö. (1993). Quality control and laboratory application guide for meat and meat products. Atatürk University, Publication No. 751. Faculty of Agriculture Spring. No: 318. Textbooks Series No: 69. Atatürk University Faculty of Agriculture Offset. 287pp, Erzurum (in Turkish).

Gökalp, H. Y., Kaya, M., \& Zorba, Ö. (1999). Meat Product Processing Engineering, Atatürk University, Faculty of Agriculture Offset, Erzurum (in Turkish).

Hernandez-Jover, T., Izquierdo-Pulido, M., Veciana-Nogues, M. T., MarineFont, A., \& Vidal-Carou, M. C. (1997). Effect of starter cultures on biogenic amine formation during fermented sausage production. Journal of Food Protection, 60(7), 825-830. https://doi.org/10.4315/0362-028X-60.7.825.

International Organization for Standardization. (1997). International standards meat and meat product. Determination of moisture content. Geneva, Switzerland: ISO 1442, https://www.iso.org/standard/6037.html

International Organization for Standardization (1999). Meat and ProductsMeasurement of pH-Reference Method. Geneva, Switzerland: ISO 2917 https://www.iso.org/standard/24785.html

International Organization for Standardization. (2003). Horizontal Method for the Enumaration of Microorganism. Colony Count Technique at $30^{\circ} \mathrm{C}$. ISO 4833 . https://www.iso.org/standard/34524.html

Koç, H., Camc1, H., Kadiroğlu, A., \& Gür, K. (2006). A study on the evaluation of selected poppy lines in terms of morphine ratios. Journal of Herbal Research, $1,31-35$.

Lopez-Diaz, T. M., Alonso, C., Roman, C., Garcia-Lopez, M. L., \& Moreno, B. (2000). Lactic acid bacteria isolated from a hand-made blue cheese. Food Microbiology, 17(1), 23-32. https://doi.org/10.1006/fmic.1999.0289.

Olgunoğlu, I. A., Özogul, F., Özogul, Y., \& Kuley, E. (2009). Chemical, sensory and microbiological assessment of marinated anchovy (Engraulis encrasicholus L., 1758) fillets stored at $1 \pm 1$ C. Advances in Food Sciences, 31(2), 1-8.

Özdestan, Ö., Güngör, F. Ö., Alpözen, E., Güven, G., \& Uren A. (2011) Determination of biogenic amines of black olives obtained from Gemlik olives grown in different regions. Olive Science, (1), 13-20.

Pichhardt, K. (1993). Lebensmittelmikrobiologie. 3. Auflage. Springer Verlag, Berlin, New York, Paris, Tokyo, London, Hong Kong, Barcelona, Budapest.

Roig-Sagués, A., \& Eerola, S. (1997). Biogenic amines in meat inoculated with Lactobacillus sake starter strains and an amine-positive lactic acid bacterium. Zeitschrift für Lebensmitteluntersuchung und-Forschung A, 205(3), 227-231.

Shalaby, A. R. (1996). Significance of biogenic amines to food safety and human health. Food research international, 29(7), 675-690.

Santos, M. S. (1996). Biogenic amines: their importance in foods. International journal of food microbiology, 29(2-3), 213-231. https://doi.org/10.1016/0168 1605(95)00032-1.

Senoz, B., Isikli, N., \& Çoksoyler, N. (2000). Biogenic amines in Turkish sausages (sucuks). Journal of Food Science, 65(5), 764-767. https://doi.org/10.1111/j.1365-2621.2000.tb13583.x.

Ten Brink, B., Damink, C., Joosten, H. M. L. J., \& In't Veld, J. H. (1990). Occurrence and formation of biologically active amines in foods. International journal of food microbiology, 11(1), 73-84. https://doi.org/10.1016/0168 1605(90)90040-C

Toy, N. (2010). Investigation of The Effects of Cell Free Extract From Lactic Acid Bacteria on Growth and Biogenic Amine Production of Food-Borne Pathogens (Master dissertation, Çukurova University, Institute of Science and Technology).

Somer, V. F. (2013). Determination of microbiological, physicochemical properties and biogenic amine contents of durable yogurts (Doctoral dissertation, Mehmet Akif Ersoy University, Institute of Science and Technology).

Yerlikaya, P., \& Gökoğlu, N. (2002). Biogenic amines and their importance in foods. Journal of Food Engineering, 6(12), 24-30. 